ISSN 1411 - 0067 Jurnal Ilmu-Ilmu Pertanian Indonesia. Volume 9, No. 2, 2007, Hlm. 130 - 138

\title{
PADI ORGANIK VERSUS NON ORGANIK: STUDI FISIOLOGI BENIH PADI (Oryza sativa L.) KULTIVAR LOKAL ROJOLELE
}

\author{
ORGANIC VERSUS NON-ORGANIC RICE: A CASE STUDY OF SEED \\ PHYSIOLOGY OF RICE (Oryza sativa L.) LOCAL CULTIVAR ROJOLELE
}

\author{
Dody Priadi, Tatang Kuswara dan Usep Soetisna \\ Pusat Penelitian Bioteknologi-LIPI Jl. Raya Bogor Km.46 Cibinong 16911 \\ d_priadi@telkom.net
}

\begin{abstract}
Study of the effect of organic and non-organic farming practice of rice (Oryza sativa L.) cv. Rojolele on seed physiology was carried out in Cipanas, West Java (on-farm) and in the laboratory of BSJ3 and greenhouse of RC for Biotechnology (off-farm). Parameters were recorded particularly on seed germination percentage, water content, dormancy behavior and morphology. On-farm study results showed that germination percentage of organic seeds was higher $(88.3 \%$ at water content of $13.4 \%)$ than those non-organic seeds $(20.0 \%$ at water content of $10.2 \%$ ). Results of off-farm study showed that the plant height of those organic seeds was higher than those non-organic seeds. On-farm practice the harvest after 150 days showed that the non-organic seeds produced more yellow grains $(44.8 \%)$ than those of organic seeds $(39.6 \%)$. A total grain per plant produced by the non-organic seeds was higher than those organic seeds, however, total percentage of the filled out organic seeds was higher (57.8\%) than those non-organic seeds $(40.1 \%)$. Organic seeds seem to be more dormant than those non-organic seeds after storage for 12 months. Grain weight of both non-organic and organic was 17-19g per 1000 seeds. Germination of off-farm non-organic seeds was $98.0 \%$, whereas those organic seeds were $95.0 \%$ at water content of $10.8 \%$ respectively. In view of seed physiology, organic rice quality better than those nonorganic because they contain more filled out seeds, even though the organic rice harvesting time longer than those non-organic. Although off-farm study represented seed physiology of either organic or non-organic seeds, on-farm study needs to be further done on all aspects of seed physiology.
\end{abstract}

Key words: rice, Oryza sativa L., Rojolele, organic farming, seeds

\begin{abstract}
ABSTRAK
Penelitian ini dilakukan untuk mengetahui pengaruh sistem pertanian organik dan non-organik secara on-farm (sawah) dan off-farm (laboratorium dan rumah kaca) terhadap aspek fisiologi benih padi (Oryza sativa L.) kv. Lokal Rojolele. Penelitian secara on-farm dilakukan di Cipanas, Jawa Barat, sedangkan penelitian secara off-farm dilakukan di laboratorium BSJ 3 Puslit Bioteknologi. Parameter yang diamati adalah, daya perkecambahan, kadar air, perilaku dormansi dan morfologinya. Hasil penelitian on-farm menunjukkan bahwa daya perkecambahan padi organik lebih tinggi (88.3\% pada kadar air $13.4 \%$ ) dari pada non-organik (20.0\% pada kadar air $10.2 \%)$. Hasil penelitian off-farm menunjukkan bahwa perawakan tanaman padi organik lebih tinggi daripada non-organik, padahal pada waktu ditanam secara on-farm tingginya tidak berbeda. Hasil panen off-farm padi non-organik pada umur 150 hari menghasilkan biji yang berwarna kuning lebih banyak (44.8\% ) dari pada organik (39.6\%). Jumlah butir per tanaman yang dihasilkan oleh tanaman non-organik lebih banyak daripada yang organik, tetapi persentase jumlah biji bernas tanaman organik setiap rumpun lebih banyak (57.8\%) daripada non-organik (40.1\%). Setelah disimpan selama 12 bulan, benih organik menjadi dorman, sedangkan padi non-organik langsung berkecambah. Berat padi non-organik maupun organik berkisar antara $17-19 \mathrm{~g}$ per 1000 butir. Daya perkecambahan off-farm padi non-organik adalah 98\% sedangkan organik adalah 95\% masing-masing pada kadar air $10.8 \%$. Ditinjau dari aspek fisiologis benih kualitas padi organik lebih baik daripada non-organik karena mengandung jumlah biji bernas yang lebih banyak, walaupun hari panen menjadi lebih panjang. Meskipun hasil percobaan off-farm dapat menggambarkan perbedaan aspek fisiologis antara benih organik dan non-organik, penelitian secara on-farm harus dilakukan untuk mengkaji aspek fisiologis benih yang lebih luas.
\end{abstract}

Kata kunci : padi, Oryza sativa L., Rojolele, pertanian organik, benih 


\section{PENDAHULUAN}

Pertanian organik merupakan jawaban atas dampak revolusi hijau yang digalakkan pada era tahun 60-an yang telah menyebabkan kesuburan tanah menjadi berkurang dan kerusakan lingkungan akibat pemakaian pupuk dan pestisida kimiawi yang tidak terkendali. Menurut Utami dan Handayani (2003), sistem pertanian yang berbasis bahan high input energy (bahan fosil) seperti pupuk kimia dan pestisida dapat merusak sifatsifat tanah dan akhirnya menurunkan produktivitas tanah untuk waktu yang akan datang. Di sisi lain konsep pertanian organik menitikberatkan pada keterpaduan antara sektor pertanian dan peternakan dalam menjamin daur hara yang optimum (Johannsen et al, 2005)

Pada pertanian organik pupuk dan pestisida yang digunakan bersumber dari bahan organik dan pupuk kandang yang berasal dari limbah tumbuhan atau hewan atau produk sampingan seperti kompos jerami padi atau sisa-sisa tanaman lainnya (Balasubramanian and Bell, 2003), sedangkan untuk pencegahan dan pemberantasan hama dan penyakit, digunakan biopestisida yang berasal dari ekstrak bahan-bahan aktif tumbuhan.

Hingga saat ini praktek pertanian organik masih diperdebatkan. Pihak yang kontra menyangsikan bahwa cara ini tidak akan mengimbangi penyediaan kebutuhan pangan seiring dengan laju pertambahan jumlah penduduk, tapi pihak yang pro seperti The Soil Association and Sustain (2001) berpendapat bahwa sebenarnya persediaan pangan dunia sudah cukup. Menurut lembaga ini terjadinya kelaparan disebabkan oleh adanya kemiskinan bukan karena tidak terpenuhinya pangan di dunia.

Pertanian yang intensif dapat merusak kesuburan tanah dan tidak berkesinambungan sebaliknya praktek pertanian organik dapat menghasilkan pangan secara berkesinambungan sehingga membantu masyarakat untuk menghasilkan bahan pangan murah dan juga mengandung hanya sedikit bahan pencemar sehingga mengurangi risiko keracunan makanan. Di samping itu sistem pertanian organik lebih mengutamakan pencegahan daripada pemberantasan hama dan penyakit, sehingga dapat mengurangi penggunaan pestisida yang dapat merusak lingkungan, biaya produksinya lebih murah, tidak merusak kesuburan tanah dan kesinambungan ketersediaan bahan organik, serta tidak merugikan makhluk hidup lain. Sistem pertanian organik juga dapat memperbaiki sifat kimia tanah dengan peningkatan $\mathrm{P}$ tersedia, $\mathrm{N}$ total, $\mathrm{K}$ tersedia, kandungan karbon, asam humat, asam fulfat dan menjaga kestabilan $\mathrm{pH}$ tanah (Utami dan Handayani, 2003). Menurut Wiguna et al. (2005), praktek pertanian organik di Indonesia telah lama diterapkan oleh masyarakat Bali melalui sistem subak, yaitu praktek pertanian yang menggunakan konsep keserasian antara Tuhan, manusia dan lingkungan.

Di dunia terdapat kurang lebih 22 jenis padipadian (Oryza). Jenis O. sativa dan $O$. glaberrima adalah jenis yang dibudidayakan, sedangkan sisanya adalah jenis-jenis liar. $O$. sativa adalah jenis yang paling tersebar ke seluruh dunia. Rojolele merupakan salah satu varietas unggul lokal yang dikembangkan di Indonesia. Varietas ini telah ditetapkan sebagai varietas unggul karena disenangi petani dan konsumen, rasa nasi lebih enak/pulen, di samping itu harga berasnya tinggi hampir dua kali lipat dari harga IR 64. (Keputusan Menteri Pertanian Nomor: 126/Kpts/TP.240/2/ 2003).

Tujuan penelitian ini adalah untuk melihat sistem pertanian organik dan non-organik terhadap aspek fisiologi padi varietas Rojolele yang ditanam secara on- dan off-farm. Disebut off-farm karena memakai bahan padi yang berasal dari pertanian organik dan non organik tetapi dilakukan di laboratorium dan rumah kaca.

\section{METODE PENELITIAN}

\section{On-farm}

Sumber benih dan pupuk

Benih padi yang digunakan pada penelitian di sawah percobaan (on-farm) adalah varietas Rojolele lokal Cianjur hasil pembibitan secara organik. Sawah percobaan berlokasi di daerah Cipanas, Cianjur, Jawa Barat pada ketinggian 950 $\mathrm{m}$ di atas permukaan laut dengan curah hujan rata- 
rata pertahun $3000 \mathrm{~mm}$. Sebagai kontrol digunakan varietas Rojolele yang ditanam secara nonorganik.

Pupuk organik yang digunakan terdiri atas campuran pupuk kandang dengan kotoran ayam, sedangkan biopestisida yang digunakan adalah campuran ekstrak $1 \mathrm{~kg}$ daun mimba (Azadirachta indica A. Juss) dengan ekstrak $1 \mathrm{~kg}$ daun nangka belanda (Annona murricata Linn.) yang dilarutkan dalam $10 \mathrm{~L}$ air. Sebelum digunakan, biopestisida tersebut disimpan selama 24 jam. Rincian perlakuan penanaman padi Rojolele secara non-organik dan organik dapat dilihat pada Tabel 1.

\section{Pengukuran kadar air}

Kadar air benih diukur berdasarkan prosedur dari ISTA (1996). Benih padi organik maupun nonorganik masing-masing sebanyak 100 biji dikeringkan di dalam oven (Heraeus T20P, Jerman) pada suhu $130{ }^{\circ} \mathrm{C}$ selama 2 jam. Pengukuran kadar air tersebut dilakukan dalam 3 ulangan.

\section{Prosedur perkecambahan}

Benih padi organik dan non-organik dipecahkan dormansinya dengan cara direndam dengan air panas pada suhu $50^{\circ} \mathrm{C}$ selama 2 jam dan selanjutnya direndam kembali dengan air selama 24 jam (ISTA, 1996). Perkecambahan dilakukan dalam 3 ulangan, setiap ulangan terdiri atas 25 benih padi yang diletakkan di atas kertas tisu komersial yang sudah dilembabkan dengan akuades. Benih padi dikecambahkan dengan metode UKDdp (Uji Kertas Digulung dengan plastik) (Sadjad, 1993), kemudian dimasukkan ke dalam germinator (Seedburo, USA) yang diatur pada suhu $28 \pm 1^{\circ} \mathrm{C}$.

\section{Off-farm}

\section{Sumber benih}

Percobaan di laboratorium dan rumah kaca (off-farm) menggunakan benih hasil dari percobaan di sawah percobaan.

\section{Prosedur perkecambahan dan penanaman}

Perkecambahan dan pertumbuhan vegetatif adalah tahap awal dari proses pertumbuhan dan perkembangan padi. Tahap selanjutnya adalah perkembangan bagian reproduktif dan proses pematangan butiran biji (Hartmann et al., 1990). Untuk melihat pengaruh dormansi benih pada hasil pertanian organik maupun non-organik, maka benih dikecambahkan tanpa perlakuan pematahan dormansi terlebih dahulu. Dormansi adalah sifat yang dapat diwariskan tetapi dipengaruhi juga oleh keadaan lingkungan selama proses pematangan biji.

Benih padi dikecambahkan dengan metode UKDdp kemudian ditanam di dalam "sawah buatan" yaitu bak plastik berukuran 35 x 30 x 13 $\mathrm{cm}$ berisi substrat tanah yang diairi secukupnya. Setiap perlakuan terdiri dari 2 ulangan, setiap ulangan terdiri dari 10 benih. Tanaman padi selalu terendam dengan air kran dan tidak diberi pupuk sampai waktu dipanen. Setelah mulai berbunga, tanaman ditutup menggunakan kasa plastik untuk menghindari serangan hama serangga.

Tabel 1. Rincian data penanaman padi Rojolele di sawah percobaan

\begin{tabular}{lll}
\hline \hline Data penanaman & \multicolumn{1}{c}{ Non-organik } & \multicolumn{1}{c}{ Organik } \\
\hline Dosis benih & & $--25 \mathrm{~kg} \mathrm{ha}^{-1}$--- \\
Dosis pupuk & $\mathrm{N}=150 \mathrm{~kg}, \mathrm{P}=75 \mathrm{~kg} \mathrm{~K}=75 \mathrm{~kg}$ & 5 ton ha $\mathrm{h}^{-1}$ terdiri atas pupuk organik \\
Sistem irigasi & Alami dari sumber mata air & Alami dari sumber mata air \\
Umur saat panen & & $--118 \mathrm{hari}--$ \\
Jarak tanam (cm) & & $--20 \times 20 \mathrm{~cm} \mathrm{---}$ \\
Pestisida & Caracron-Delcis & Campuran ekstrak Azadirachta indica dan \\
& & Annonamuricata \\
\hline
\end{tabular}




\section{HASIL DAN PEMBAHASAN}

On-farm

Produksi

Padi non-organik dan organik yang ditanam di sawah percobaan dengan perlakuan seperti pada Tabel 1 menghasilkan masing-masing 0.6 ton gabah kering per $1000 \mathrm{~m}^{2}$. Hal ini menunjukkan bahwa penggunaan pupuk organik sama efektifnya dengan pupuk kimiawi sehingga menghasilkan jumlah yang sama, meskipun masih harus dilakukan pengujian mutu berasnya. Penelitian Arafah dan Sirappa (2003) yang menggunakan pupuk organik yang bersumber dari jerami membuktikan bahwa pertumbuhan dan hasil tanaman yang menggunakan pupuk organik lebih tinggi dibanding tanpa pupuk organik baik secara tunggal maupun interaksinya dengan pupuk N, P, dan K. Produksi gabah yang sama dengan sistem non-organik tersebut tidak terlepas dari peranan penggunaan campuran ekstrak daun mimba dan nangka belanda sebagai biopestisida. Ekstrak biji mimba juga sebelumnya terbukti efektif untuk mengendalikan kutu jenis Megalurothrips sjostedti pada tanaman kacang panjang (Vigna unguiculata) (Saxena and Kidiavai, 1997). Jenis tanaman lain yang efektif untuk mengendalikan serangga hama Spodoptera litoralis adalah Aglaia spectabilis yang bahan aktifnya berasal dari ekstrak kulit mimba (Schneider et al, 2000). Faktor-faktor lain yang berpengaruh terhadap produksi seperti sifat-sifat tanah diasumsikan sama karena penelitian on-farm ini dilakukan di lokasi yang sama.

Meskipun produksi padi organik sama dengan non-organik, secara ekonomi beras organik lebih menguntungkan karena harga beras organik di pasaran lebih tinggi, apalagi ditunjang dengan semakin banyaknya orang yang peduli akan kebutuhan pangan yang terbebas dari pestisida kimiawi. Pertanian organik semakin berkembang sejalan dengan timbulnya kesadaran akan pentingnya menjaga kelestarian lingkungan dan kebutuhan akan bahan makanan yang relatif sehat (Rahmawati, 2005).
Tabel 2. Hasil pengukuran kadar air benih padi yang dihasilkan secara on-farm

\begin{tabular}{ccc}
\hline \hline \multirow{2}{*}{ Ulangan } & \multicolumn{2}{c}{ Kadar air (\%) } \\
\cline { 2 - 3 } & Organik & Non-organik \\
\hline 1 & 13.4 & 8.9 \\
2 & 13.3 & 10.8 \\
3 & 13.5 & 11.0 \\
\hline Rataan & 13.4 & 10.2 \\
\hline
\end{tabular}

Tabel 3. Daya perkecambahan (\%) padi organik dan non-organik varietas Rojolele dari sawah percobaan di Cipanas

\begin{tabular}{ccc}
\hline $\begin{array}{c}\text { Umur perkecambahan } \\
\text { (minggu) }\end{array}$ & Organik & Non-organik \\
\hline 1 & $82.8 \pm 5.38$ & $13.3 \pm 6.70$ \\
2 & $85.0 \pm 4.32$ & $18.8 \pm 5.91$ \\
3 & $88.3 \pm 4.27$ & $20.0 \pm 6.22$ \\
\hline
\end{tabular}

\section{Kadar air}

Hasil pengukuran kadar air benih menunjukkan bahwa ketika sampai di laboratorium kadar air rataan padi organik adalah $13.4 \%$ sedangkan non-organik adalah lebih rendah yaitu $10.2 \%$ (Tabel 2). Kadar air yang sudah cukup berkurang tersebut akibat dari tertahannya hasil panen di lapang atau karena proses pengeringan sebelum dilakukan pengujian kadar air. Padi umumnya dipanen pada waktu kadar airnya 22$26 \%$ untuk selanjutnya dikeringkan menjadi sekitar $14 \%$ seperti berlaku di pasaran gabah komersial

\section{Daya perkecambahan}

Hasil uji daya perkecambahan (Tabel 3) menunjukkan bahwa secara umum daya perkecambahan padi hasil pertanian organik lebih tinggi empat kali lebih dari non-organik, yaitu 88.3\% pada minggu ketiga. Percobaan Pirdashti et al. (2003) pada beberapa genotip padi menunjukkan bahwa persentase perkecambahan dan pertumbuhan kecambah akan berkurang dengan bertambahnya cekaman air. Menurut Hartmann et al. (1990), air diserap oleh biji kering sehingga kadar airnya meningkat dengan cepat sampai pada tingkat tertentu. Air dapat melunakkan lapisan biji dan menyebabkan hidrasi pada protoplasma. Perlakuan pemanasan pada 
suhu $50{ }^{\circ} \mathrm{C}$ dan perendaman dengan air selama 48 jam pada percobaan ini bertujuan untuk menghilangkan pengaruh dormansi yang biasa terdapat pada jenis padi-padian.

Setelah disimpan selama 12 bulan benih padi organik maupun non-organik diuji kembali daya perkecambahannya dengan atau tanpa pematahan dormansi di dalam air selama 48 jam untuk mematahkan dormansinya (Gambar 1). Hasil pengamatan menunjukkan bahwa benih padi nonorganik sudah mulai berkecambah padi hari pertama proses pengecambahan. Daya perkecambahannya meningkat terus seiring dengan waktu sampai pada hari ke 5 (89\%). Selanjutnya daya perkecambahan tidak berubah lagi sampai akhir pengamatan. Benih padi nonorganik tidak menjadi dorman setelah penyimpanan selama 12 bulan, sebaliknya benih padi organik menjadi dorman dan sama sekali tidak berkecambah sampai akhir pengamatan.

Hal tersebut menunjukkan bahwa perendaman di dalam air selama 48 jam tanpa direndam terlebih dahulu pada air yang bersuhu $50{ }^{\circ} \mathrm{C}$ tidak cukup kuat untuk mematahkan dormansi biji padi organik. Penelitian Miyoshi and Sato (1997) pada padi indica dan japonica menunjukkan bahwa penggunaan ethanol dalam keadaan aerob merupakan prosedur yang efektif untuk untuk mengupas kulit biji dalam rangka pematahan dormansi benih padi karena berdasarkan penelitian sebelumnya terbukti bahwa pengupasan biji segera setelah panen dapat merangsang perkecambahan pada padi indica tetapi tidak pada padi japonica.

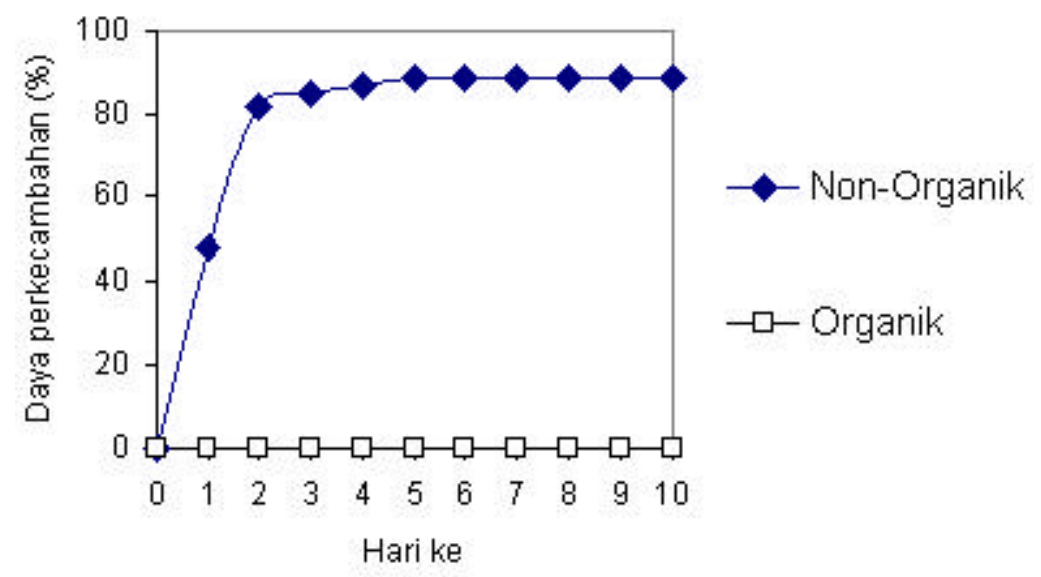

(A)

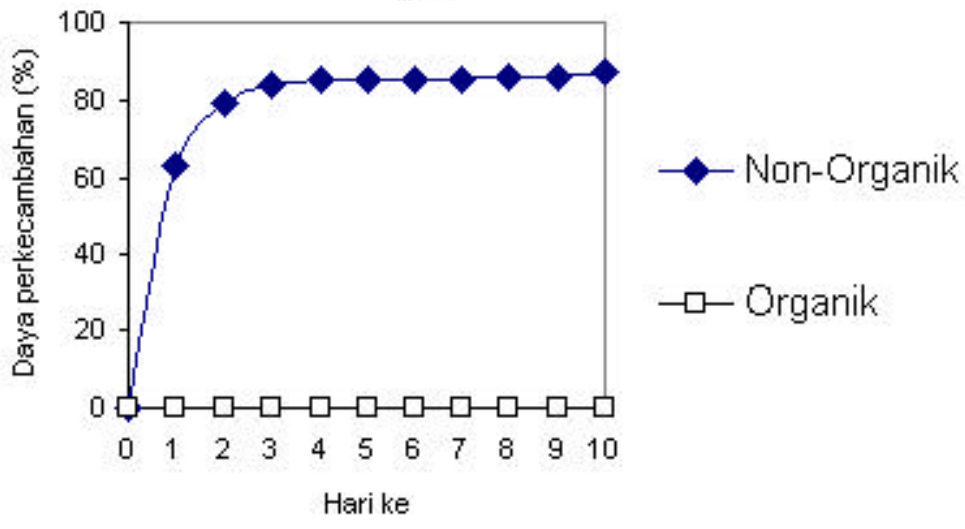

(B)

Gambar 1. Daya perkecambahan benih padi non-organik dan organik A. Tanpa perlakuan pematahan dormansi, B. Direndam dengan air kran selama 48 jam. Data diambil dari 3 ulangan, masing-masing ulangan terdiri atas 100 benih. 


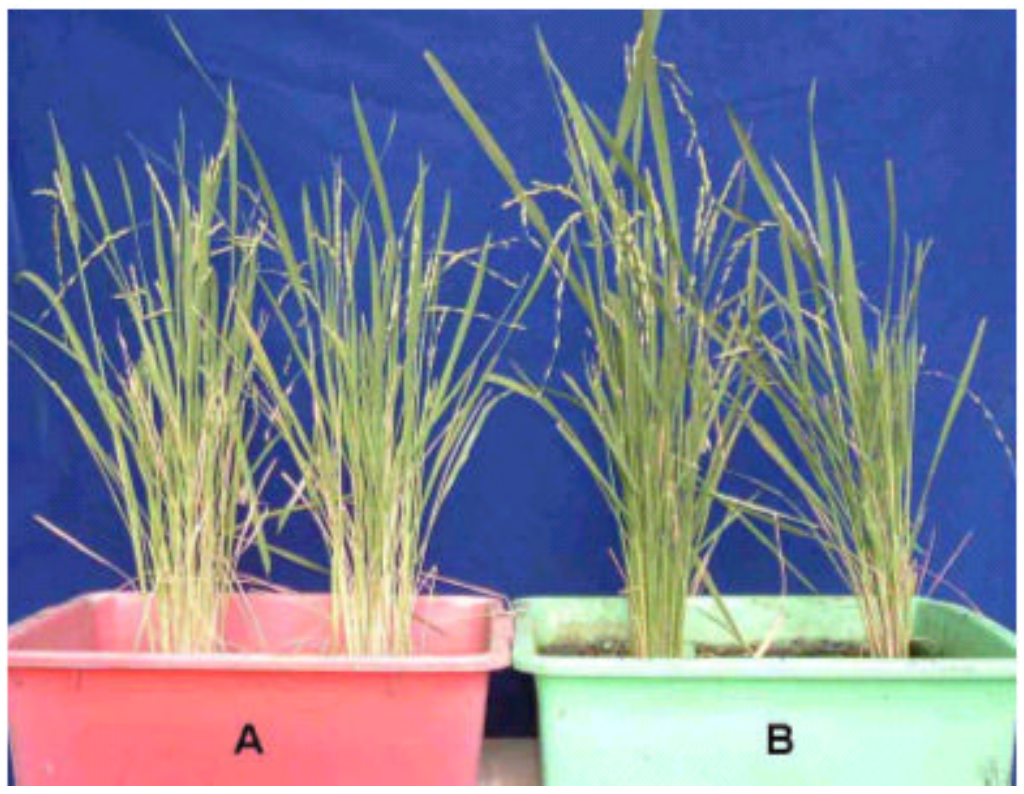

Gambar 2. Perawakan tanaman padi yang sedang berbuah A. Nonorganik, B. Organik pada petak sawah buatan

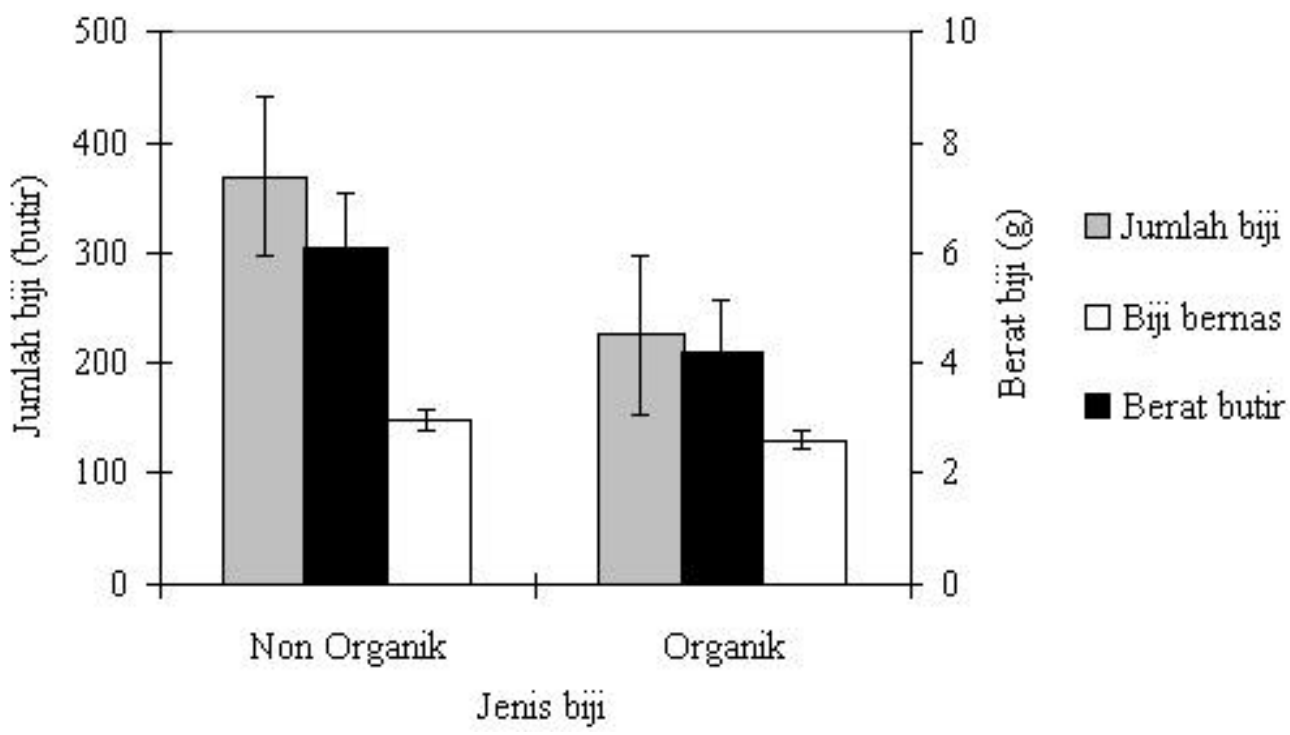

Gambar 3. Klasifikasi biji yang dihasilkan secara off-farm

Off-farm

Perawakan tanaman

Meskipun padi ditanam secara off-farm pada bak plastik, penampilan morfologi tanaman padi varietas Rojolele umumnya tidak menunjukkan perubahan secara nyata, yaitu sesuai dengan pertelaan yang tercantum pada SK Menteri Pertanian Nomor: 126/Kpts/TP.240/2/2003, yakni: Bentuk tanaman tegak; Tinggi tanaman 146-155 cm; Warna kaki ungu; Warna daun hijau; Muka daun kasar; Bentuk gabah gemuk; Warna gabah kuning. 


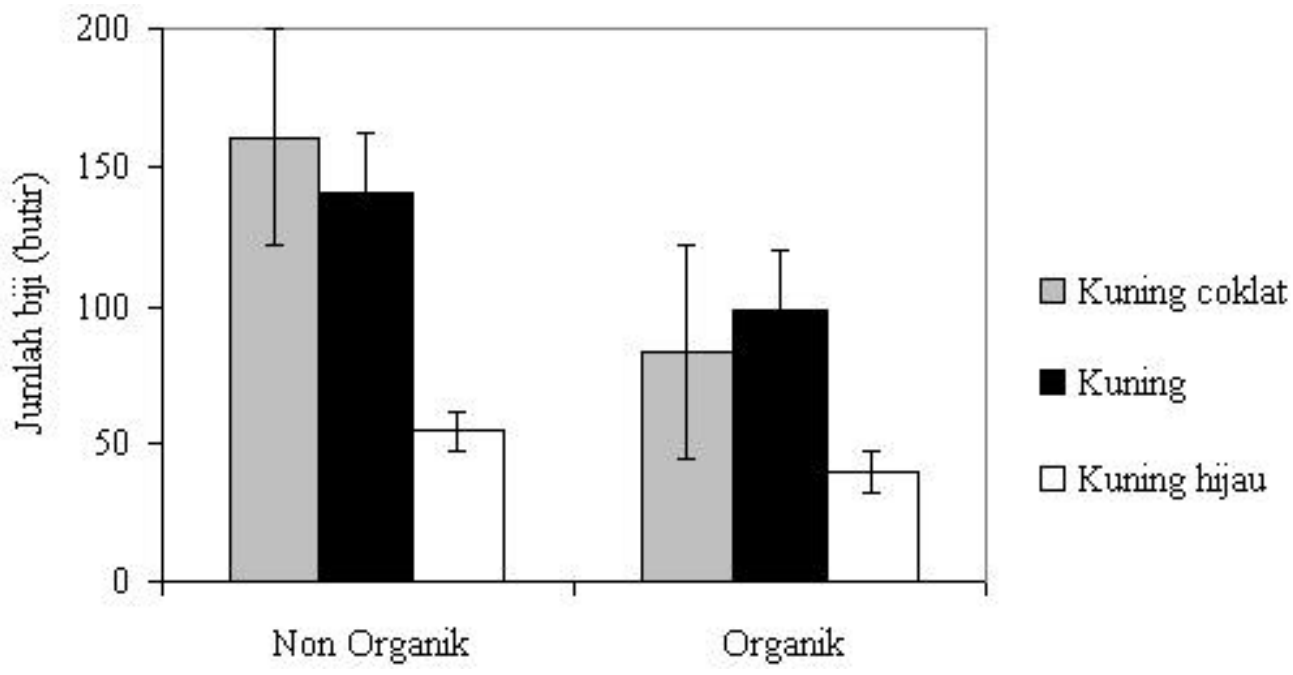

Gambar 4. Klasifikasi biji yang dihasilkan dari penanaman secara off-farm

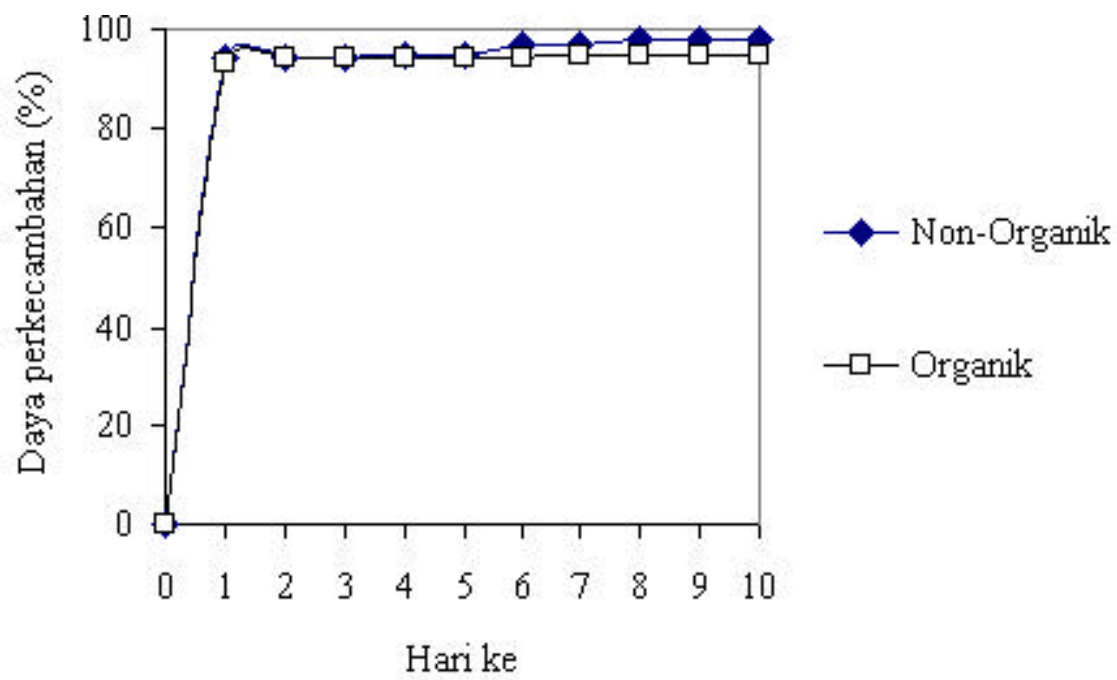

Gambar 7. Daya perkecambahan benih padi non-organik dan organik. Benih direndam dengan air panas $\left(50^{\circ} \mathrm{C}\right)$ kemudian direndam selama 48 jam sebelum dikecambahkan. Data diambil dari 4 ulangan, masing-masing ulangan terdiri dari 25 benih.

Hasil pengamatan pada daun tanaman padi yang sedang berbuah menunjukkan bahwa warna daun padi organik lebih hijau daripada non-organik (Gambar 2). Setelah berumur 2 bulan tanaman mulai berbunga dan pada umur 150 hari tanaman telah matang fisiologis dan cukup umur untuk dipanen.

\section{Pengamatan pasca panen}

Hasil panen menunjukkan bahwa jumlah biji yang dihasilkan setiap tanaman non-organik ukurannya lebih besar daripada organik, tetapi persentase jumlah biji bernas tanaman organik (57.8\%) lebih tinggi daripada non-organik (40.1\%), sedangkan berat rataan baik biji non-organik 
maupun organik berkisar antara 17-19 g per 1000 butir (Gambar 4).

Tabel 4. Hasil pengukuran kadar air benih padi yang dihasilkan secara off-farm

\begin{tabular}{ccc}
\hline \hline \multirow{2}{*}{ Ulangan } & \multicolumn{2}{c}{ Kadar air (\%) } \\
\cline { 2 - 3 } & Organik & Non-organik \\
\hline 1 & 10.8 & 10.9 \\
2 & 10.6 & 10.8 \\
3 & 10.9 & 10.8 \\
\hline Rataan & 10.8 & 10.8 \\
\hline
\end{tabular}

Meskipun jumlah biji yang dihasilkan padi nonorganik lebih banyak, persentase biji yang berwarna kuning (39.6\%) lebih rendah dari pada padi organik $(44.8 \%)$, tetapi pada umur masak fisiologis, padi organik masih mengandung biji berwarna kuning hijau lebih banyak (17.6\%) dari pada biji non-organik (15.2\%) (Gambar 4). Hal ini berarti bahwa pada padi organik masih dimungkinkan diperoleh tambahan hasil panen dari gabah yang masih hijau menjadi gabah berwarna kuning siap panen. Pada akhirnya terbukti bahwa pertanian organik memberikan panen yang relatif lebih tinggi, walaupun umur panen yang lebih lama.

\section{Kadar air}

Hasil pengukuran kadar air hasil panen di petak percobaan menunjukkan bahwa baik padi organik maupun non-organik mengandung kadar air yang tidak jauh berbeda yaitu sekitar 10.6-10.9 $\%$ (Tabel 4). Kadar air padi organik maupun nonorganik pada petak percobaan relatif homogen karena lingkungannya lebih terkontrol bila dibandingkan dengan yang ditanam secara onfarm.

\section{Daya Perkecambahan}

Hasil uji perkecambahan sebelumnya menunjukkan bahwa padi organik menjadi dorman setelah disimpan selama 12 bulan. Setelah dipatahkan dormansinya dengan air panas pada suhu $50^{\circ} \mathrm{C}$ dan diikuti dengan perendaman dalam air (suhu $27-28{ }^{\circ} \mathrm{C}$ ) selama 48 jam, padi organik tersebut dapat tumbuh mencapai $95 \%$, sedangkan padi non-organik $98 \%$ setelah dikecambahkan selama 10 hari (Gambar 5).

\section{KESIMPULAN}

Ditinjau dari aspek fisiologis benih, secara offfarm, kualitas padi organik lebih baik daripada nonorganik karena mengandung jumlah biji bernas yang lebih banyak, walaupun hari panen menjadi lebih panjang.Untuk mengkaji secara lebih luas harus dilakukan percobaan penanaman di sawah percobaan (on-farm) agar dapat diperoleh data yang lebih akurat.

\section{UCAPAN TERIMA KASIH}

Ucapan terima kasih disampaikan kepada Sdr. Yadi sebagai Teknisi yang telah memelihara dan merawat tanaman percobaan di laboratorium maupun rumah kaca selama penelitian.

\section{DAFTAR PUSTAKA}

Arafah dan M. P. Sirappa. 2003. Kajian Penggunaan Jerami dan Pupuk N, P, dan K pada Lahan Sawah Irigasi. Jurnal Ilmu Tanah dan Lingkungan 4 (1): 15-24.

Balasubramanian, V and M.Bell. 2003. Organic Materials and Manures. Rice Science for Better World. International Rice Research Institute (IRRI). http://www. knowledge bank.irri.org/troprice. December 04, 2003. Hartmann, H.T., D.E. Kester and F.T. Davies. 1990. Plant Propagation: Principles and Practices. Prentice-Hall International Inc. ,New Jersey

International Seed Testing Association (ISTA). 1996. International Rules for Seed Testing 1996. Seed Science and Technology 21 (Suppl.): 1B288.

Johannsen, J., A. Mertineit, B. Wilhelm, R. Buntzel-Cano, F. Schöne, and M. Fleckenstein. 2005. Organic farming, A contribution to sustainable poverty alleviation in developing countries? German NGO Forum Environment \& Development.

Keputusan Menteri Pertanian Nomor: 126/Kpts/ TP.240/2/2003 Tentang Pelepasan Galur Padi Sawah Lokal Rojolele Sebagai Varietas Unggul Dengan Nama Rojolele. 
Miyoshi, K. and T. Sato. 1997. The Effects of Ethanol on the Germination of Seeds of Japonica and Indica Rice (Oryza sativa L.) under Anaerobic and Aerobic Condition. Annals of Botany 79: 391-395.

Pirdashti, H., Z.T. Sarvestani, G.H. Nematzadeh and A. Ismail. 2003. Effect of Water Stress on Seed Germination and Seedling Growth of Rice (Oryza sativa L.) Genotypes. Pakistan Journal of Agronomy 2 (4): 217-222,

Rahmawati, N. 2005. Pemanfaatan Biofertilizer pada Pertanian Organik. Fakultas Pertanian Universitas Sumatera Utara.

Sadjad, S. 1993. Dari Benih Kepada Benih. Grasindo, Jakarta.

Saxena, R.C. and E.L. Kidiavai1. 1997. Neem Seed Extract Spray Applications as LowCost Inputsfor Management of the Flower Thrips in the Cowpea Crop. Phytoparasitica 25(2):99-110

Schneider, C., F.I. Bohnenstengel, B.W. Nugroho, V. Wray, L. Witte, P.D. Hung, L.C. Kiet and
P. Proksch. 2000. Insecticidal Rocaglamide Derivatives from Aglaia spectabilis. Phytochemistry 54: 731-736

Soejadi dan Udin S. Nugraha. 2001. Studi Efikasi Metode Pematahan Dormansi Benih Padi. Penelitian Pertanian Tanaman Pangan 20(1): 72-80.

The Soil Association and Sustain: the alliance for better food and farming. 2001. Myth and Reality, Organik vs Non-Organik: The Facts. http://www.soilassociation.org. August 11, 2006.

Utami, S.N.H. dan S. Handayani. 2003. Sifat Kimia Entisol Pada Sistem Pertanian Organik. Ilmu Pertanian 10(2): 63-69.

Wiguna, I.W.A.A, R.P. Lorenzen and S. Lorenzen. 2005. Past, Present and Future Perspectives of Balinese Rice Farming. http:/ /www.rspas.anu.edu.au/ rmap/projects/ _docs/Lorenzen_farming.pdf. August 11, 2006 